\title{
The Client's Perspective of Vendor IT Governance Practices and Service Quality in Malaysian Outsourcing Context
}

\author{
Mohd Kamil Lob Ahmad Kasri $^{1}$ and Norshidah Mohamed ${ }^{2}$ \\ ${ }^{2}$ College of Business Administration, Prince Sultan University, Saudi Arabia \\ ${ }^{1,2}$ International Business School, Universiti Teknologi Malaysia, Malaysia
}

Correspondence should be addressed to: Norshidah Mohamed; norshidah.mohamed@gmail.com

Received date: 28 August 2017; Accepted date: 8 December 2017; Published date: 6 Mars 2018

Academic Editor: Norol Hamiza Zamzuri

Copyright $@$ 2018. Mohd Kamil Lob Ahmad Kasri and Norshidah Mohamed . Distributed under Creative Commons CC-BY 4.0

\begin{abstract}
The research examines the client's perspective of outsourcing vendor information technology (IT) governance practices and service quality. Using a cross-sectional survey approach, the researchers distributed a total of 100 questionnaires to employees at six client organizations in Malaysia that outsource selected IT functions to a local IT vendor. The research uses SPSS Statistics 17.0 and Smart PLS Version 3 for data analysis. The evidence suggests that from client's perspective, vendor IT governance practices impact on service quality in IT outsourcing environment.
\end{abstract}

Keywords: IT outsourcing, IT governance, IT service quality, survey research, structural equation modelling

\section{Introduction}

The Information Age today is characterized by an economy that largely depends on information. Hence, the organizations rely heavily on the quality of information services being used. Attempts to achieve sustainable competitiveness through the information technology (IT), however, they have placed a considerable burden on organizations as the scope and complexity of IT expands. Increasingly, the organizations rely on outsourcing to focus on core competencies (Grover et al., 1996; Gupta and Gupta, 1992) and to manage their cost better (Ang and Straub, 1998; Claver et. al., 2002).

Cite this Article as: Mohd Kamil Lob Ahmad Kasri and Norshidah Mohamed (2018)," The Client's Perspective of Vendor IT Governance Practices and Service Quality in Malaysian Outsourcing Context", Journal of Southeast Asian Research, Vol. 2018(2018), Article ID 919986, DOI: 10.5171/2018.919986 
IT outsourcing is a strategic decision. IT outsourcing is not a new concept for business. ${ }^{1}$ Generally, IT outsourcing is the practice of contracting with a third party service provider (or vendor) for some or all of an organization's IT functions. IT outsourcing has been practiced, notably in the United States of America (USA) since the late eighties. Significant examples of IT outsourcing are Kodak's outsourcing its IT functions to IBM $^{2}$ and General Motors' (GM) outsourcing its IT functions to EDS. ${ }^{3}$ In the current global IT services environment, IT outsourcing practices are evolving as many organizations continue to identify the opportunities and the benefits.

Gartner forecasted global spending for IT outsourcing services would be $\$ 251.7$ billion in 2012. This was a growth of $2.1 \%$ over 2011 and a projected compound annual growth rate of $5.9 \%$ from 2012 through $2016 .{ }^{4}$ More recently, it was reported that the global IT outsourcing market could expect Compound Annual Growth Rate (CAGR) of $5.84 \%$ by 2019.5

With IT outsourcing, the organizations are challenged to manage a large spending on IT outsourcing and intricacies of outsourcing relationships. The Organizations equally face the risks of business frauds and natural disasters. The last two decades witness continuous debates amongst practitioners and the researchers on best practices in IT governance as organizations face these challenges. Accordingly, regulatory frameworks are instituted in assuring sound business systems and adequate internal controls. Sarbanes-Oxley Act (SOX) 2002, in particular, was enacted to enhance corporate governance, foster organizational responsibilities, strengthen internal controls and increase accountabilities (Damianides, 2004). Concurrently, the industry and the academia saw the emergence and participate in the development and adoption of IT governance principles, standards and framework (e.g. COBIT, ITIL, PMBOK, ISO27001). Each framework addresses specific objectives. Each framework defines specific top management level responsibilities and requires that they exercise due diligence in their roles. This governance development is largely driven by the need for transparency in managing organizational risks and safeguarding of shareholder value. The general concern of IT governance framework in implementation and monitoring of performance of IT investments includes IT control structure, protection of IT investment, security and control of IT, assurance of information integrity and quality of IT service delivery (Mohamed and Kaur, 2012).

IT vendors recognize the need to position themselves in responding to such challenging trend. Concurrently, client organizations need to consider how their vendor fits into the mix including areas outsourced. This challenge is further heightened by the popularity of selective outsourcing or multi outsourcing procurement models. The need for effective governance increases dramatically and the success of outsourcing contracts is critically dependent on the quality of the governance framework between the service recipient (client) and vendor. Increasingly, vendors are expected to demonstrate that their services align with IT governance best practices.

Prior literature shows a growing discussion among the researchers on the impact of IT governance on organizational performance (Mohamed and Kaur, 2012; Mangalaraj et al. 2014; Lunardi et al. 2014; Pang, 2014; Tsai et al. 2015). While financial performance, balanced scorecard and strategic alignment are among the most common measure for organizational performance in IT governance impact research, outsourcing does not appear to be a key research context. In a recent literature, Tsai et al. (2015) investigated the mediating effects of IT governance on service quality and Enterprise Resource Planning (ERP) performance. While the research considered vendor service quality and consultant service quality, the research, however, confined to the implementation of ERP system. Further and 
more recently, there is a call for IT governance research to connect to information systems effectiveness as IT governance research in the past appears to place a greater emphasis on internal control and compliance (Mangalaraj et al. 2014).

Therefore, this paper aims at presenting empirical findings in encouraging additional research in IT governance. IT service quality is chosen as an impact of IT governance in the context of IT outsourcing in responding to identified gaps in prior research and to this recent call. The research aspires to advance understanding of the impacts of outsourcing vendor IT governance practices on service quality.

Hence, the research question (RQ) is:

RQ: Do extensive outsourcing vendor's IT governance practices impact on client's perceived IT service quality?

The objective of the research is to develop and test a theoretical model on vendor IT governance practices and IT service quality from client's perspective. The research aims at gaining insights into client's perspective of vendor IT governance practices and IT service quality in an IT outsourcing arrangement.

\section{Literature Review}

This section reviews the literature on IT governance and IT service quality.

\section{IT Governance}

The word governance is derived from the Greek verb kubernao meaning to steer. According to the IT Governance Institute (2005), IT governance is the responsibility of the board of directors and executive management. This is an integral part of enterprise governance. Van Grembergen (2000) refers to IT governance as the ability of organizations to achieve specified goals or organizational capacity, exercised by the board, executive management and IT management to control the formulation and implementation of IT strategy and to ensure the fusion of business and IT. Essentially, IT governance consists of leadership and organizational structures and processes that ensure the organization's IT sustains and extends the organization's strategies and objectives (De Haes and Van Grembergen, 2004; 2005).

Symons et al. (2005) defined IT governance as the process by which decisions are made around IT investments. IT governance covers the practice of how decisions are made, who makes the decisions, who is accountable for the decisions and how the results of decisions are measured and monitored. Executive commitment is vital in ensuring the role that IT plays in enabling and executing the enterprise's strategy. IT governance does not exist in isolation; IT governance is a subset of enterprise governance (Korac - Kakabadse and Kakabadse, 2001). It is the responsibility of not just of the IT management but of the board of directors and executive management (Peterson, 2004). Concurrently, Weill and Ross (2004) support the notion by requiring senior levels to specify decisions rights and an accountability framework to encourage desirable behavior in the use of IT. The activity of governance itself improves the understanding and thus the working relationship between IT and the rest of the business. As a result, the organizations that institute best practices in IT governance could expect business value and benefits (Kan, 2003) that are readily identified and that include increased revenues, profits and a balance struck between value creation (i.e. risk taking) and security (i.e. risk managing) (IT Governance Institute, 2000; Symons et al. 2005). Research indicates that board-level IT governance influence organizational performance regardless of IT needs (Turel and Bart, 2014) and that firms adopting IT governance practices improve their profitability (Lunardi et al., 2014).

Extant literature indicates poor governance and management of outsourcing relationships as the primary reason for the 
failure of outsourcing ventures (McFarlan and Nolan, 1995; Kern and Willcocks, 2000). A good structure of governance in an IT outsourcing relationship refers to the development of a good contract (Barthélemy, 2003). The outsourcing contract provides a detailed specification of "the exchanges of services and products, financial matters, assets and staff transfers, communication and information exchanges, service enforcements and monitoring methods, key personnel, dispute resolution procedures and other formal issues" (Kern and Willcocks, 2000).

\section{Perceived IT Service Quality}

Service quality refers to the overall support delivered by a service provider. This is regardless whether such support is handled by the IT department, a new organizational unit or outsourced to an Internet service provider (DeLone and McLean, 2003). The quality of service is thought to be the core criterion for overall customer service (Parasuraman et al., 1991). Service quality has been reported to be significantly related to costs, profitability, customer satisfaction, customer retention, behavior intention and positive word of mouth communications
(Cronin and Taylor, 1992). Over the years, the SERVQUAL instrument (Zeithaml et al., 1990) has been used to measure five elements of service quality:

Tangibles - appearance of physical facilities, equipment, personnel and communication materials.

Reliability - the ability to perform the promised service dependably and accurately.

Responsiveness - the willingness to help customers and provide prompt service.

Assurance - the knowledge and courtesy of employees and their ability to convey trust and confidence.

Empathy - caring, individualized attention which the organization provides to its customers.

\section{Research Hypotheses and Research Model}

The objective of the research is to investigate the client's perspective of outsourcing vendor IT governance practices and service quality. Accordingly, the research aims at answering the research question of whether outsourcing vendor IT governance practices impact on its IT service quality. Figure 1 shows the conceptual research framework.

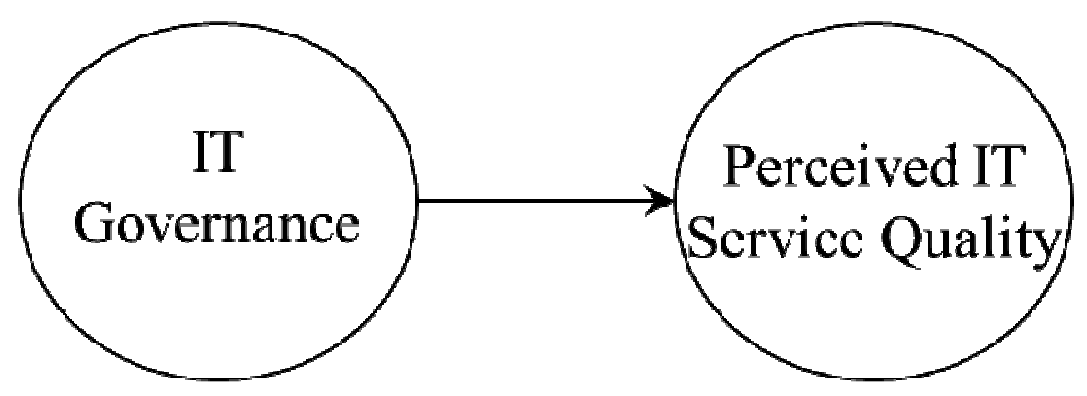

Fig. 1: Conceptual research framework

Based on the aforementioned review, the research aims at developing a research model and testing a set of hypotheses. This is in seeking out an evidence for the relationship between IT governance and perceived IT service quality in an IT outsourcing arrangement. IT governance in the research comprises vendor's involvement at the top level in IT planning with the client, IT governance processes to ensure smooth execution of plans and adequate monitoring, and vendor-client outsourcing relationship. In this research, perceived IT service quality comprises soft issues that cover 
responsiveness, assurance, empathy and reliability. Accordingly, the hypotheses are listed below:

H1a: Vendor's IT governance structure is positively associated with its IT governance processes.

H1b: Vendor's IT governance structure is positively associated with its IT governance relational mechanism.

H2a: Vendor's IT governance processes are positively associated with its responsiveness to the client.

H2b: Vendor's IT governance processes are positively associated with its assurance to the client. H2c: Vendor's IT governance processes are positively associated with its empathy to the client. H2d: Vendor's IT governance processes are positively associated with its reliability to the client.

H3a: Vendor's IT governance relational mechanism is positively associated with its responsiveness to the client.

H3b: Vendor's IT governance relational mechanism is positively associated with its assurance to the client.

H3c: Vendor's IT governance relational mechanism is positively associated with its empathy to the client.

H3d: Vendor's IT governance relational mechanism is positively associated with its reliability to the client.

The research model is in Figure 2.

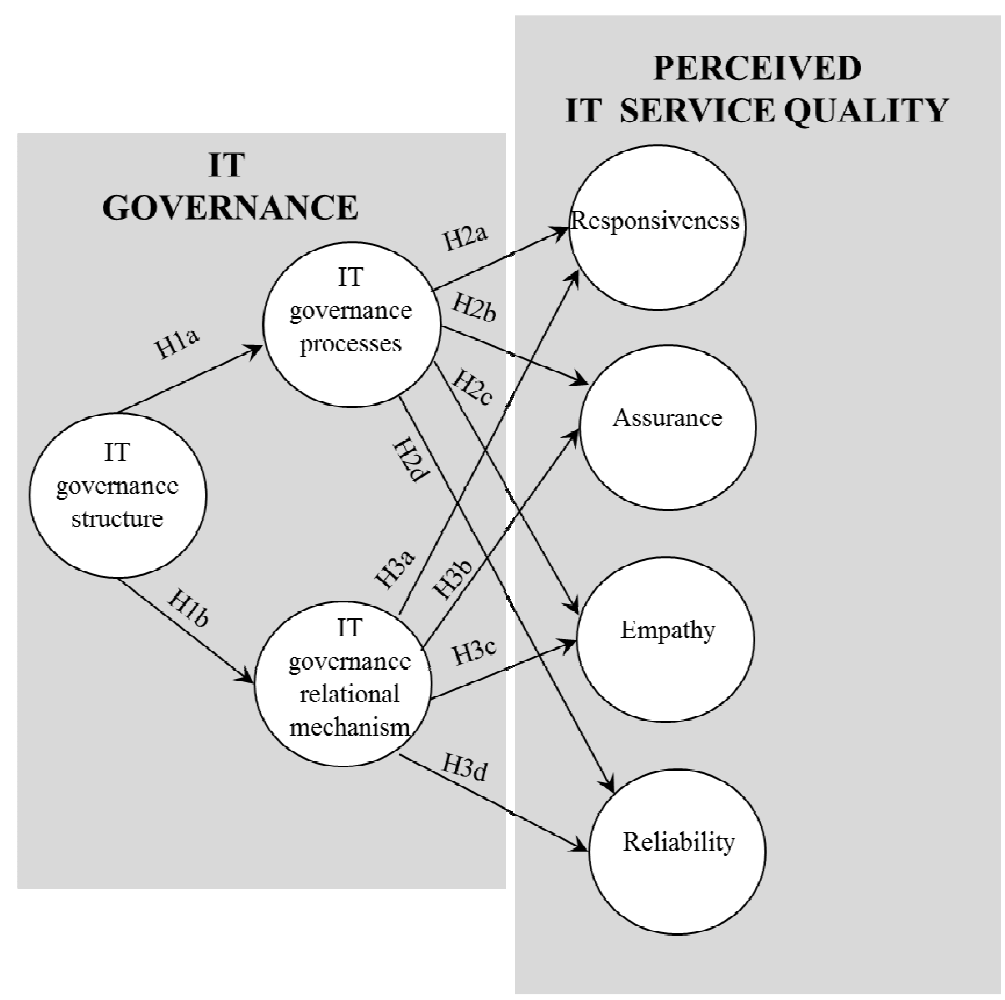

Fig. 2: Research model

\section{Methodology}

This section discusses the research context, data collection and instrument, and data analysis approach for the research.

\section{Research context}

The research aims at finding empirical evidence on the relationship between vendor IT governance practices and IT service quality from client's (end user's) perspective. 
A total of six client organizations were selected for the research. All client organizations are based in Malaysia. The outsourcing vendor is a leading public listed company who has been providing IT outsourcing services since the 1980s. Malaysia was selected as the research context due to its potential to further expand its IT service offerings within the Southeast Asia region. A recent newspaper report indicates that the IT outsourcing industry in Malaysia was set to double in growth by 2017 with a CAGR of $15 \%$ from its current 2012 revenue of US\$1.7billion. ${ }^{6}$

\section{Data Collection and Instrument}

The research used a survey questionnaire as data collection approach. The survey questionnaire is in English and is divided into three parts: Section A, Section B and Section C. Section $A$ of the questionnaire seeks to gain information about the profile of the respondents. This section covers personal information such as age, gender, education and job level, duration of work experience and whether respondent is from the IT unit of the organization. Section $B$ of the questionnaire contains questions about respondent's perceived IT service quality of the vendor. For this section, a five point Likert scale was used. A five-point represents "strongly agree" while a one-point represents "strongly disagree". Section C of the questionnaire contains questions about respondent's perception of vendor IT governance practices. A five point Likert scale was also used for this section. A one- point represents "not at all", a two-point represents "a little", a three point represents "moderately", a four-point represents "extensively" and a five-point represents "very extensively". Survey items using Likert scale were based on prior studies. IT governance measures were adapted from De Haes and Van Grembergen (2008a, b). Perceived IT service quality measures were adapted from Pitt et al. (1995) and Sherman (1997).

In line with the research context, only those from the supervisory, middle management and senior management in the client organization were selected as respondents to the survey questionnaire. Target respondents should have regular interaction with staffs representing the outsourcing vendor. Respondents were from either the IT unit of their organizations or other non IT units. IT outsourcing services rendered by the vendor include helpdesk and desktop management services, and IT back end infrastructure services which cover servers, applications and network operations management.

A pilot test of the survey questionnaire was conducted among 40 respondents. Cronbach's Alpha coefficient is used to determine reliability of measures. A coefficient above 0.70 indicates internal consistency (Hair et al. 1998; Nunnally 1978). The result of reliability analysis indicates that all items were reliable (Table 1)

Table 1: Pilot test reliability analysis

\begin{tabular}{|l|c|r|}
\hline Constructs & No. of items & Cronbach's Alpha \\
\hline Perceived IT service quality & 9 & 0.916 \\
\hline IT governance & 11 & 0.901 \\
\hline
\end{tabular}

A total of 100 survey questionnaires were distributed to respondents of six targeted client organizations. All six organizations are large in size having more than 500 employees. Each organization has different business focus. The research used convenience sampling in view of fulfilling the criteria as set out to be in line with the research context as discussed earlier. 
Each respondent was briefed about the purpose of the research, and was given a week to provide responses to the questionnaire and to return it to the researchers. A total of 92 questionnaires were received and used for data analysis.

\section{Data analysis}

Data collected from the respondents were first entered, coded, cleaned and analyzed using SPSS Statistics 17.0. Analysis at this stage covers gaining insights into respondent's profile (descriptive statistics), profile of variables (descriptive statistics) and checking for group differences (due to the participation of respondents from several organizations). Descriptive statistics will be discussed in the subsequent section. Using Kruskal Wallis test (each sample within an organization is fewer than 30), all except two items show no significant difference among the cases. The two items $(\mathrm{p}<0.05)$ were (i) the outsourcing vendor gives prompt services (measures responsiveness) (ii) corporate internal communication addressing general IT issues (measures IT governance relational mechanism). As these two items constitute only $10 \%$ of total items, the researchers considered all cases as one sample. Subsequently, data were analyzed using Smart PLS Version 3 to determine the relationship among variables in answering the research question.

\section{Results}

This section presents and discusses the results of data analysis. Data analysis covers descriptive statistics and assessment of measurement and structural model.

\section{Profile of respondents}

Table 2 shows the profile of respondents.

Table 2: Profile of respondents

\begin{tabular}{|l|l|r|r|}
\hline Characteristics & Item & Frequency & $\begin{array}{c}\text { Percentage } \\
\text { (\%) }\end{array}$ \\
\hline Age & $20-29$ & 25 & 27.2 \\
\hline & $30-39$ & 45 & 48.9 \\
\hline & $40-49$ & 20 & 21.7 \\
\hline & $50-59$ & 2 & 2.2 \\
\hline & Total & 92 & 100.0 \\
\hline Gender & Male & 40 & 43.5 \\
\hline & Female & 52 & 56.5 \\
\hline & Total & 92 & 100.0 \\
\hline Years / current job & $1-5$ & 55 & 59.8 \\
\hline & $6-10$ & 23 & 25.0 \\
\hline & $11-15$ & 10 & 10.8 \\
\hline & $16-20$ & 2 & 2.2 \\
\hline & More than 20 & 2 & 2.2 \\
\hline & Total & 92 & 100.0 \\
\hline Job level & Non-Executive & 24 & 26.1 \\
\hline & Executive & 41 & 44.6 \\
\hline & Supervisor & 6 & 6.5 \\
\hline & Manager & 16 & 17.4 \\
\hline
\end{tabular}

Mohd Kamil Lob Ahmad Kasri and Norshidah Mohamed (2018), Journal of Southeast Asian Research, DOI: $10.5171 / 2018.919986$ 


\begin{tabular}{|l|l|r|r|}
\hline & Senior Manager & 5 & 5.4 \\
\hline & Total & 92 & 100.0 \\
\hline Highest education & Up to equivalent & 36 & 39.2 \\
\hline & grade 12 education & & \\
\hline & Bachelor's degree & 50 & 54.3 \\
\hline & Master's degree & 6 & 6.5 \\
\hline & Total & 92 & 100.0 \\
\hline
\end{tabular}

In terms of age group, 25 respondents $(27.2$ $\%$ ) were between the age of 20 and 29. The remaining $(72.8 \%)$ are 30 years and above. In terms of gender, there were more female respondents $(56.5 \%)$ with male respondents being the remaining (43.5\%) proportion.

The number of respondents in the range from 1 to 5 years in their current job is 55 (59.8\%). This represents the majority in work duration. Only four (4.4\%) of the total respondents have been in the current job for 16 years or more. The remaining proportion (35.8\%) has served in their current job between 6 and 15 years.

A majority of the respondents (73.9\%) are in management positions ranging from supervisory to middle management and/or senior management. Out of the total respondents, $5.4 \%$ represent the senior management.

A high proportion of the respondents $(60.8$ $\%$ ) were educated at the Bachelor's degree or higher. The rest (39.2\%) of the sample had at least an equivalent of grade 12 education. Based on the predominant age group that is above 30 years of age, educational background, job level and experience in the current job, the respondents would be generally familiar with management evaluation process.

\section{Profile of variables}

Table 3 shows the profile of perceived IT service quality variables.

Table 3: Profile of perceived IT service quality variables

\begin{tabular}{|c|c|c|c|c|c|c|c|}
\hline \multirow[t]{2}{*}{ Code } & Item & \multirow[t]{2}{*}{ SD } & \multirow[t]{2}{*}{$\bar{D}$} & \multirow[t]{2}{*}{$\mathbf{N}$} & \multirow[t]{2}{*}{$\bar{A}$} & \multirow[t]{2}{*}{ SA } & \multirow[t]{2}{*}{ Mean } \\
\hline & The outsourcing vendor: & & & & & & \\
\hline OV 11 & $\begin{array}{l}\text { gives prompt services } \\
\text { (measures } \\
\text { responsiveness) }\end{array}$ & 0 & $\begin{array}{c}3 \\
(3.3 \%)\end{array}$ & $\begin{array}{c}23 \\
(25 \%)\end{array}$ & $\begin{array}{c}50 \\
(54.3 \%)\end{array}$ & $\begin{array}{c}16 \\
(17.4 \%)\end{array}$ & 3.86 \\
\hline OV 12 & $\begin{array}{l}\text { is always willing to help } \\
\text { (measures } \\
\text { responsiveness) }\end{array}$ & 0 & $\begin{array}{c}2 \\
(2.2 \%)\end{array}$ & $\begin{array}{c}13 \\
(14.1 \%)\end{array}$ & $\begin{array}{c}56 \\
(60.9 \%)\end{array}$ & $\begin{array}{c}21 \\
(22.8 \%)\end{array}$ & 4.04 \\
\hline OV 13 & $\begin{array}{l}\text { is consistently courteous } \\
\text { to me (measures } \\
\text { assurance) }\end{array}$ & 0 & 0 & $\begin{array}{c}19 \\
(20.7 \%)\end{array}$ & $\begin{array}{c}55 \\
(59.7 \%)\end{array}$ & $\begin{array}{c}18 \\
(19.6 \%)\end{array}$ & 3.99 \\
\hline OV 14 & $\begin{array}{l}\text { has knowledge to answer } \\
\text { clients questions } \\
\text { (measures assurance) }\end{array}$ & 0 & $\begin{array}{c}2 \\
(2.2 \%)\end{array}$ & $\begin{array}{c}27 \\
(29.3 \%)\end{array}$ & $\begin{array}{c}53 \\
(57.6 \%)\end{array}$ & $\begin{array}{c}10 \\
(10.9 \%)\end{array}$ & 3.77 \\
\hline OV 15 & $\begin{array}{l}\text { gives me personal } \\
\text { attention (measures } \\
\text { empathy) }\end{array}$ & 0 & $\begin{array}{c}6 \\
(6.5 \%)\end{array}$ & $\begin{array}{c}29 \\
(31.5 \%)\end{array}$ & $\begin{array}{c}46 \\
(50 \%)\end{array}$ & $\begin{array}{c}11 \\
(12 \%)\end{array}$ & 3.67 \\
\hline
\end{tabular}

Mohd Kamil Lob Ahmad Kasri and Norshidah Mohamed (2018), Journal of Southeast Asian Research, DOI: 10.5171/2018.919986 


\begin{tabular}{|l|l|c|c|c|c|c|c|}
\hline OV 16 & $\begin{array}{l}\text { understand my needs } \\
\text { and those of my work } \\
\text { group (measures } \\
\text { empathy) }\end{array}$ & 0 & $\begin{array}{c}4 \\
(4.3 \%)\end{array}$ & $\begin{array}{c}29 \\
(31.5 \%)\end{array}$ & $\begin{array}{c}42 \\
(45.7 \%)\end{array}$ & $\begin{array}{c}17 \\
(18.5 \%)\end{array}$ & 3.78 \\
\hline OV 17 & $\begin{array}{l}\text { delivers when promises } \\
\text { to do something } \\
\text { (measures reliability) }\end{array}$ & 0 & $\begin{array}{c}5 \\
(5.4 \%)\end{array}$ & $\begin{array}{c}25 \\
(27.2 \%)\end{array}$ & $\begin{array}{c}46 \\
(50 \%)\end{array}$ & $\begin{array}{c}16 \\
(17.4 \%)\end{array}$ & 3.79 \\
\hline OV 18 & $\begin{array}{l}\text { show sincere interest in } \\
\text { solving problems } \\
\text { encountered by myself or } \\
\text { others in my work group } \\
\text { (measures reliability) }\end{array}$ & 0 & $\begin{array}{c}8 \\
(8.7 \%)\end{array}$ & $\begin{array}{c}21 \\
(22.8 \%)\end{array}$ & $\begin{array}{c}(53.3 \%) \\
(15.2 \%)\end{array}$ & 3.75 \\
\hline OV 19 & $\begin{array}{l}\text { performs services right } \\
\text { the first time (measures } \\
\text { reliability) }\end{array}$ & 0 & $\begin{array}{c}6 \\
(6.5 \%)\end{array}$ & $\begin{array}{c}36 \\
(39.2 \%)\end{array}$ & $\begin{array}{c}37 \\
(40.2 \%)\end{array}$ & $\begin{array}{c}13 \\
(14.1 \%)\end{array}$ & 3.62 \\
\hline
\end{tabular}

Overall, the majority of respondents were inclined towards agreeing with each measure of IT service quality. The mean ranges from 3.62 (the outsourcing vendor performs services right first time - measures reliability) to 4.04 (the outsourcing is always willing to help - measures responsiveness).

Table 4 shows the profile of IT governance variables.

Table 4: Profile of IT governance variables

\begin{tabular}{|c|c|c|c|c|c|c|c|}
\hline \multirow[t]{2}{*}{ Code } & Item & \multirow[t]{2}{*}{ NAA } & \multirow[t]{2}{*}{ AL } & \multirow[t]{2}{*}{$\mathbf{M}$} & \multirow[t]{2}{*}{$\mathbf{E}$} & \multirow[t]{2}{*}{ VE } & \multirow[t]{2}{*}{ Mean } \\
\hline & $\begin{array}{l}\text { The IT outsourcing vendor } \\
\text { practices: }\end{array}$ & & & & & & \\
\hline VP20 & $\begin{array}{l}\text { documentation of business } \\
\text { and IT governance } \\
\text { alignment tasks (measures } \\
\text { structure) }\end{array}$ & 0 & $\begin{array}{c}7 \\
(7.6 \%)\end{array}$ & $\begin{array}{c}47 \\
(51.1 \%)\end{array}$ & $\begin{array}{c}30 \\
(32.6 \%)\end{array}$ & $\begin{array}{c}8 \\
(8.7 \%)\end{array}$ & 3.42 \\
\hline VP21 & $\begin{array}{l}\text { involvement of their senior } \\
\text { members in our } \\
\text { organization at the IT } \\
\text { steering } \\
\text { committee/executive/senior } \\
\text { management level for } \\
\text { evaluation/prioritization of } \\
\text { IT investment (measures } \\
\text { structure) }\end{array}$ & $\begin{array}{c}1 \\
(1.1 \%)\end{array}$ & $\begin{array}{c}11 \\
(12 \%)\end{array}$ & $\begin{array}{c}42 \\
(45.6 \%)\end{array}$ & $\begin{array}{c}34 \\
(37 \%)\end{array}$ & $\begin{array}{c}4 \\
(4.3 \%)\end{array}$ & 3.32 \\
\hline VP22 & $\begin{array}{l}\text { making available } \\
\text { security/compliance } \\
\text { function (measures } \\
\text { structure) }\end{array}$ & 0 & $\begin{array}{c}3 \\
(3.3 \%)\end{array}$ & $\begin{array}{c}33 \\
(35.9 \%)\end{array}$ & $\begin{array}{c}50 \\
(54.3 \%)\end{array}$ & $\begin{array}{c}6 \\
(6.5 \%)\end{array}$ & 3.64 \\
\hline VP23 & $\begin{array}{l}\text { working jointly with us in } \\
\text { development and execution } \\
\text { of our strategic information } \\
\text { systems planning blueprint } \\
\text { (measures structure) }\end{array}$ & $\begin{array}{c}1 \\
(1.1 \%)\end{array}$ & $\begin{array}{c}10 \\
(10.9 \%)\end{array}$ & $\begin{array}{c}41 \\
(44.5 \%)\end{array}$ & $\begin{array}{c}32 \\
(34.8 \%)\end{array}$ & $\begin{array}{c}8 \\
(8.7 \%)\end{array}$ & 3.39 \\
\hline VP24 & $\begin{array}{l}\text { IT performance } \\
\text { measurement (e.g. IT }\end{array}$ & 0 & $\begin{array}{c}8 \\
(8.7 \%) \\
\end{array}$ & $\begin{array}{c}40 \\
(43.5 \%) \\
\end{array}$ & $\begin{array}{c}33 \\
(35.8 \%) \\
\end{array}$ & $\begin{array}{c}11 \\
(12 \%) \\
\end{array}$ & 3.51 \\
\hline
\end{tabular}

Mohd Kamil Lob Ahmad Kasri and Norshidah Mohamed (2018), Journal of Southeast Asian Research, DOI: $10.5171 / 2018.919986$ 


\begin{tabular}{|c|c|c|c|c|c|c|c|}
\hline & $\begin{array}{l}\text { Balance Scorecard) in their } \\
\text { service delivery (measures } \\
\text { process) }\end{array}$ & & & & & & \\
\hline VP25 & $\begin{array}{l}\text { conformity to Service Level } \\
\text { Agreement (SLA) delivery } \\
\text { (measures process) }\end{array}$ & $\begin{array}{c}2 \\
(2.2)\end{array}$ & $\begin{array}{c}3 \\
(3.3 \%)\end{array}$ & $\begin{array}{c}39 \\
(42.4 \%)\end{array}$ & $\begin{array}{c}34 \\
(36.9 \%)\end{array}$ & $\begin{array}{c}14 \\
(15.2 \%)\end{array}$ & 3.60 \\
\hline VP26 & $\begin{array}{l}\text { project governance } \\
\text { management methodologies } \\
\text { for managing IT projects } \\
\text { delivery (measures process) }\end{array}$ & $\begin{array}{c}2 \\
(2.2 \%)\end{array}$ & $\begin{array}{c}4 \\
(4.3 \%)\end{array}$ & $\begin{array}{c}48 \\
(52.2 \%)\end{array}$ & $\begin{array}{c}28 \\
(30.4 \%)\end{array}$ & $\begin{array}{c}10 \\
(10.9 \%)\end{array}$ & 3.43 \\
\hline VP27 & $\begin{array}{l}\text { IT budget control/reporting } \\
\text { in their performance } \\
\text { reporting delivery } \\
\text { (measures process) }\end{array}$ & $\begin{array}{c}3 \\
(3.3 \%)\end{array}$ & $\begin{array}{c}13 \\
(14.1 \%)\end{array}$ & $\begin{array}{c}46 \\
(50 \%)\end{array}$ & $\begin{array}{c}24 \\
(26.1 \%)\end{array}$ & $\begin{array}{c}6 \\
(6.5 \%)\end{array}$ & 3.18 \\
\hline VP28 & $\begin{array}{l}\text { IT governance control } \\
\text { framework (e.g. } \\
\text { COBIT/ITIL) delivery } \\
\text { (measures process) } \\
\end{array}$ & $\begin{array}{c}2 \\
(2.2 \%)\end{array}$ & $\begin{array}{c}3 \\
(3.3 \%)\end{array}$ & $\begin{array}{c}46 \\
(50 \%)\end{array}$ & $\begin{array}{c}32 \\
(34.7 \%)\end{array}$ & $\begin{array}{c}9 \\
(9.8 \%)\end{array}$ & 3.47 \\
\hline VP 29 & $\begin{array}{l}\text { Knowledge management (on } \\
\text { IT governance) delivery } \\
\text { (measures relational } \\
\text { mechanism) }\end{array}$ & $\begin{array}{c}2 \\
(2.2 \%)\end{array}$ & $\begin{array}{c}4 \\
(4.3 \%)\end{array}$ & $\begin{array}{c}41 \\
(44.6 \%)\end{array}$ & $\begin{array}{c}33 \\
(35.9 \%)\end{array}$ & $\begin{array}{c}12 \\
(13 \%)\end{array}$ & 3.53 \\
\hline VP 30 & $\begin{array}{l}\text { Corporate internal } \\
\text { communication addressing } \\
\text { general IT issues on a } \\
\text { regular basis (measures } \\
\text { relational mechanism) }\end{array}$ & $\begin{array}{c}1 \\
(1.1 \%)\end{array}$ & $\begin{array}{c}1 \\
(1.1 \%)\end{array}$ & $\begin{array}{c}37 \\
(40.2 \%)\end{array}$ & $\begin{array}{c}43 \\
(46.7 \%)\end{array}$ & $\begin{array}{c}10 \\
(10.9 \%)\end{array}$ & 3.65 \\
\hline
\end{tabular}

The mean score for IT governance measures ranges from 3.18 (IT budget control/reporting in their performance reporting delivery - measures process) to 3.65 (Corporate internal communication addressing general IT issues on a regular basis - measures relational mechanism). Findings indicate that respondents evaluated the vendor IT governance practices as moderate in line with the use of scale around the mid-point (as defined in earlier section of the paper). There is an evidence to suggest that the vendor, from client's perspective does not yet reach extensiveness in IT governance practices.
Measurement model and structural model

The subsequent step was to analyse the convergent validity. Convergent validity is achieved when loadings of the measures to respective constructs are at least 0.60 (Bagozzi and Yi, 1988; Kline, 2005), composite reliability (CR) of all constructs are above 0.6 (Bagozzi and Yi, 1988; Kline, 2005) and average variance extracted (AVE) are above 0.5 (Fornell and Larcker, 1981). Table 5 shows the loadings, composite reliability and average variance extracted. 
Table 5: Loadings, composite reliability and average variance extracted

\begin{tabular}{|c|c|c|c|c|c|}
\hline \multicolumn{2}{|c|}{ Construct } & Item & Loading & CR & AVE \\
\hline \multirow{9}{*}{$\begin{array}{l}\text { Perceived IT service } \\
\text { quality }\end{array}$} & Responsiveness & OV11 & 0.893 & \multirow[t]{2}{*}{0.891} & \multirow[t]{2}{*}{0.804} \\
\hline & Responsiveness & OV12 & 0.90 & & \\
\hline & Assurance & OV13 & 0.847 & \multirow[t]{2}{*}{0.844} & \multirow[t]{2}{*}{0.73} \\
\hline & Assurance & OV14 & 0.863 & & \\
\hline & Empathy & OV15 & 0.868 & \multirow[t]{2}{*}{0.877} & \multirow[t]{2}{*}{0.781} \\
\hline & Empathy & OV16 & 0.899 & & \\
\hline & Reliability & OV17 & 0.898 & \multirow[t]{3}{*}{0.90} & \multirow[t]{3}{*}{0.751} \\
\hline & Reliability & OV18 & 0.851 & & \\
\hline & Reliability & OV19 & 0.85 & & \\
\hline \multirow[t]{11}{*}{ IT governance } & Structure & VP20 & 0.83 & \multirow[t]{4}{*}{0.848} & \multirow[t]{4}{*}{0.651} \\
\hline & Structure & VP21 & 0.418 & & \\
\hline & Structure & VP22 & 0.788 & & \\
\hline & Structure & VP23 & 0.792 & & \\
\hline & Process & VP24 & 0.806 & \multirow[t]{5}{*}{0.876} & \multirow[t]{5}{*}{0.587} \\
\hline & Process & VP25 & 0.791 & & \\
\hline & Process & VP26 & 0.835 & & \\
\hline & Process & VP27 & 0.698 & & \\
\hline & Process & VP28 & 0.689 & & \\
\hline & Relational mechanism & VP29 & 0.871 & \multirow[t]{2}{*}{0.848} & \multirow[t]{2}{*}{0.736} \\
\hline & Relational mechanism & VP30 & 0.845 & & \\
\hline
\end{tabular}

Item VP21 highlighted in italic and bold (involvement of their senior members in our organisation at the IT steering committee/executive/senior management level for evaluation/prioritisation of IT investment) that measures structure in IT governance does not meet the cut-off loading. Therefore, the item is dropped from further analysis. The rest of the items meet the cutoff loading. The inter-variable correlations (Table 6) were then examined.

Table 6: Inter-variable correlations

\begin{tabular}{|c|c|c|c|c|c|c|c|}
\hline & Structure & Process & Relational & Responsiveness & Assurance & Empathy & Reliability \\
\hline Structure & 0.807 & & & & & & \\
\hline Process & 0.795 & 0.766 & & & & & \\
\hline Relational & 0.618 & 0.753 & 0.858 & & & & \\
\hline Responsiveness & 0.46 & 0.586 & 0.614 & 0.897 & & & \\
\hline Assurance & 0.559 & 0.608 & 0.592 & 0.686 & 0.854 & & \\
\hline Empathy & 0.606 & 0.606 & 0.587 & 0.63 & 0.726 & 0.884 & \\
\hline Reliability & 0.635 & 0.615 & 0.654 & 0.696 & 0.733 & 0.757 & 0.867 \\
\hline
\end{tabular}

The correlation among IT governance structure, process and relational mechanism ranges from 0.618 to 0.795 . This provides empirical evidence that IT governance measures correlate among each other. The correlation among perceived IT service quality ranges from 0.63 to 0.757 . This provides empirical evidence that the 
measures for perceived IT service quality correlate among each other. The square-root AVE (highlighted in bold) were higher than correlations suggesting that the construct was more closely related to its own measures thus supporting discriminant validity (Kline, 2005).

The researchers then proceeded with bootstrapping to determine support for hypotheses (Table 7).

Table 7: Support for hypotheses

\begin{tabular}{|c|c|c|c|c|c|}
\hline Hypotheses & Path & $\boldsymbol{B}$ & $\begin{array}{l}\text { Standard } \\
\text { deviation }\end{array}$ & t-Statistic & Support? \\
\hline H1a & $\begin{array}{l}\text { Structure -> } \\
\text { process }\end{array}$ & 0.80 & 0.033 & 24.242 & Yes \\
\hline H1b & $\begin{array}{l}\text { Structure -> } \\
\text { relational }\end{array}$ & 0.621 & 0.075 & 8.287 & Yes \\
\hline H2a & $\begin{array}{l}\text { Process -> } \\
\text { responsiveness }\end{array}$ & 0.289 & 0.147 & 1.966 & Yes \\
\hline H2b & $\begin{array}{l}\text { Process }-> \\
\text { assurance }\end{array}$ & 0.374 & 0.134 & 2.795 & Yes \\
\hline H2c & $\begin{array}{l}\text { Process -> } \\
\text { empathy }\end{array}$ & 0.371 & 0.134 & 2.776 & Yes \\
\hline H2d & $\begin{array}{l}\text { Process -> } \\
\text { reliability }\end{array}$ & 0.287 & 0.135 & 2.129 & Yes \\
\hline H3a & $\begin{array}{l}\text { Relational -> } \\
\text { responsiveness }\end{array}$ & 0.397 & 0.137 & 2.892 & Yes \\
\hline H3b & $\begin{array}{l}\text { Relational -> } \\
\text { assurance }\end{array}$ & 0.311 & 0.141 & 2.2 & Yes \\
\hline H3c & $\begin{array}{l}\text { Relational -> } \\
\text { empathy }\end{array}$ & 0.314 & 0.134 & 2.339 & Yes \\
\hline H3d & $\begin{array}{l}\text { Relational -> } \\
\text { reliability }\end{array}$ & 0.438 & 0.142 & 3.081 & Yes \\
\hline
\end{tabular}

H1a suggests that vendor's IT governance structure is positively associated with its IT governance processes. Support was found for this relationship $(\beta=0.80$; $\mathrm{t}-\mathrm{stat}=24.242)$.

H1b indicates that vendor's IT governance structure is positively associated with its IT governance relational mechanism. Support was found for this relationship ( $ß=0.621$; $t$ stat=8.287).

H2a proposes that vendor's IT governance processes are positively associated with its responsiveness to the client. There was support for this relationship $(B=0.289$; $t$ stat=1.966).

$\mathrm{H} 2 \mathrm{~b}$ proposes that vendor's IT governance processes are positively associated with its assurance to the client. There was support for this relationship ( $ß=0.374$; $t$-stat $=2.795)$.

$\mathrm{H} 2 \mathrm{c}$ suggests that vendor's IT governance processes are positively associated with its empathy to the client. Support was found for this relationship $(\beta=0.371$; t-stat=2.776).

H2d proposes that vendor's IT governance processes are positively associated with its 
reliability to the client. Support was found for this relationship ( $ß=0.287$; $t$-stat=2.129).

H3a suggests that vendor's IT governance relational mechanism is positively associated with its responsiveness to the client. There was support for this relationship $(~ \beta=0.397$; $t$ stat $=2.892$ ).

H3b proposes that vendor's IT governance relational mechanism is positively associated with its assurance to the client. There was support for this relationship $(B=0.311$; $t$ stat=2.2).
H3c suggests that vendor's IT governance relational mechanism is positively associated with its empathy to the client. Support was found for this relationship $(\beta=0.314 ; t$ stat $=2.339$ ).

H3d indicates that vendor's IT governance relational mechanism is positively associated with its reliability to the client. There was support for this relationship $(B=0.438$; $t$ stat=3.081).

Figure 3 shows the theoretical path results.

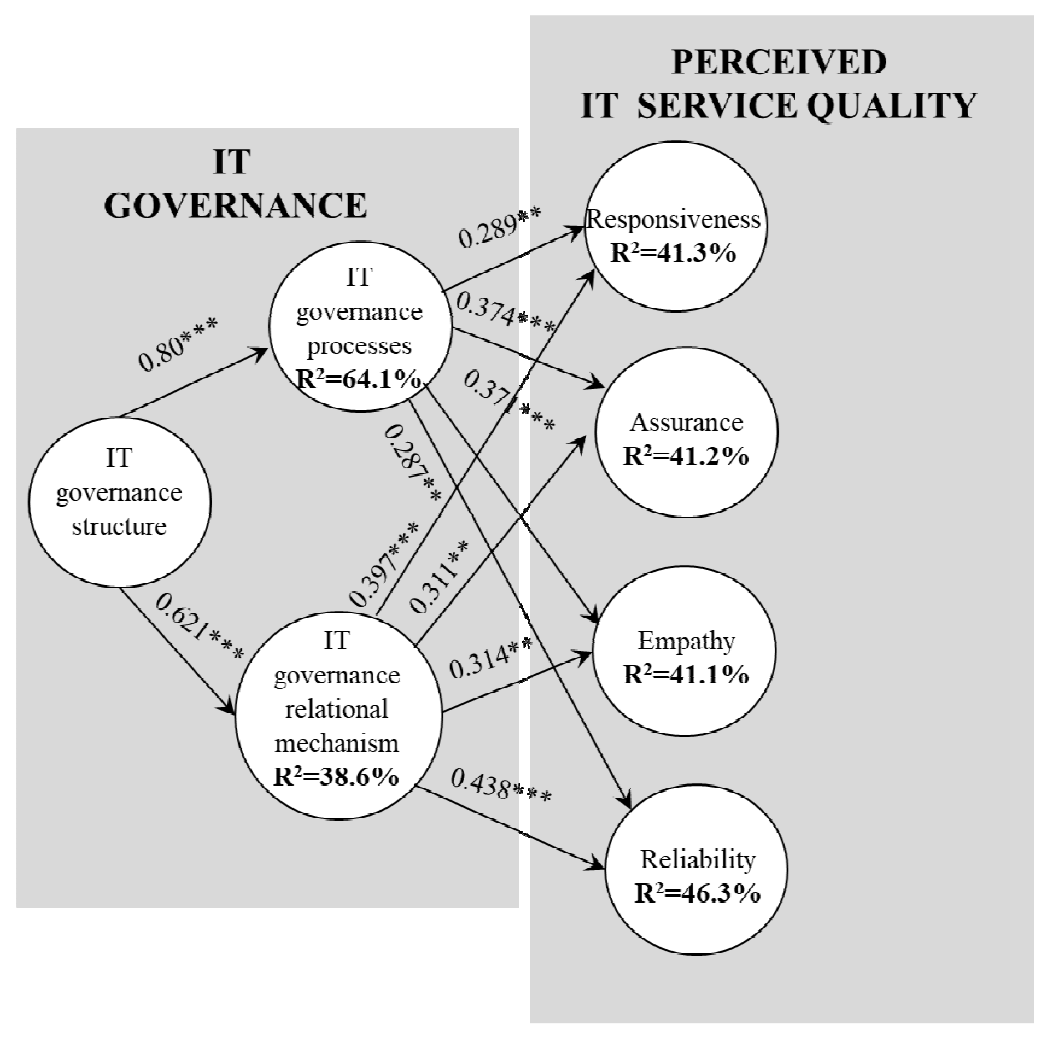

Fig. 3: Theoretical path results

Note: -> significant path. ${ }^{* *},{ }^{* * *}$ Path is significant at $\mathrm{p}<0.05$ and at $\mathrm{p}<0.01$ respectively.

A total of $64.1 \%$ variation in IT governance processes is contributed by IT governance structure alone. IT governance relational mechanism is explained through $38.6 \%$ variation contributed by IT governance structure. A total of $41.3 \%$ variation in responsiveness is jointly contributed by IT governance process and relational mechanism. Assurance is explained through $41.2 \%$ jointly contributed by IT governance 
process and relational mechanism. A total of $41.1 \%$ variation in empathy is jointly contributed by IT governance process and relational mechanism. Reliability is explained through $46.3 \%$ variation jointly contributed by IT governance process and relational mechanism.

\section{Discussion and Conclusion}

IT outsourcing is a strategy for organizations who strive to manage IT costs and focus on core competencies. Equally, organizations nowadays struggle to manage risks and safeguard shareholder value as they engage into IT outsourcing relationship. The Organizations are continuously challenged with outsourcing relationship intricacies while striving to attain organizational performance. The research sets out at gaining insights into client's perspective of vendor IT governance practices and IT service quality in an IT outsourcing arrangement. At the onset, the researchers formulated the following research question (RQ): Do extensive outsourcing vendor's IT governance practices impact on client's perceived IT service quality?

The objective of the research was set out to develop and to test a theoretical model on vendor IT governance practices and IT service quality from client's perspective. The research used survey approach. A total of 100 survey questionnaires were distributed to employees at six client organizations in Malaysia that outsource selected IT functions to a local IT vendor. A total of 92 survey questionnaires were used for analysis. The research has fulfilled the objective. The subsequent section discusses the major findings, the research contributions and the limitations and the suggestions for future research.

\section{Summary of major findings}

The research reaffirms that vendor IT governance practices comprise governance structure, process and relational mechanism in IT outsourcing context. IT governance and
IT service quality measures used in the research indicate reliability across time in outsourcing environment. The research provides evidence on the importance of vendor's having in place IT governance structure. This assures the client that vendor is capable to support client in development of IT planning blueprint, in providing secure and compliant function, and in catering to relevant documentation needs. In outsourcing context, IT governance structure requires joint involvement of vendor's senior management with the client in leading and managing critical IT function for the client. Vendors who have more extensive IT governance structure (through top management's involvement and assurance of compliance) would experience greater drive in promoting appropriate internal control framework (reporting, service level etc.) and better relationship with the clients (through meetings and communications). Clients could expect better control of their own performance and vendor's performance, when vendor practices appropriate IT governance structure. This includes establishing standards for vendor performance and implementing relevant performance measurement tools when outsourcing. Regular communication and knowledge sharing between client and vendor about IT governance and issues arising in outsourcing are essential. This finding resonates McFarlan and Nolan, (1995), Kern and Willcocks (2000) and Barthélemy (2003).

In this research, perceived IT service quality was conceptualized as the impact of IT governance. IT service quality is measured through client's assessment of vendor. There is an evidence to suggest that vendor extensive IT governance process and IT governance relational mechanism contribute to higher IT service quality from client's perspective. Client would experience greater responsiveness from vendor (in terms of willingness to provide prompt services and assistance) for vendor that practice more extensive IT governance. Further, there is indication that vendor practicing more 
extensive IT governance is more courteous to client and is better able to demonstrate knowledge on client's outsourcing concerns. Besides, client could expect vendor that practice more extensive IT governance to pay greater attention to client, to better fulfill promises and to deliver services right the first time. In sum, this finding is in support of Turel and Bart (2014) and Lunardi et al. (2014).

\section{Research contributions}

From a theoretical perspective, the research identified perceived IT service quality as impacts of IT governance. The research has developed a theoretical model that explains IT governance and perceived IT service quality from client's perspective in IT outsourcing context. Notably, the research lends support for the role of IT governance in explaining perceived IT service quality. As the measures demonstrate internal consistency, IT vendors could adopt the measures. This contributes to practice. The use of structural equation modelling is demonstrated for IT governance research thereby adding to methodological contribution.

\section{Limitations and suggestions for future research}

The first limitation of the research is the small sample size of 92 respondents. The small sample was a limiting factor in determining group differences for IT governance practice and perceived IT service quality. Secondly, a convenience sampling was used for the research. Thirdly, data was collected at a point of time. Future research could consider higher number of respondents, other client and vendor organizations and a longitudinal approach.

\section{Endnotes}

${ }^{1}$ https://www.technavio.com/report/globalito-and-bpo-it-outsourcing-market (accessed on August 8, 2017)

${ }^{2}$ http://www.computerweekly.com/feature/ CW50-A-history-of-IT-outsourcing (accessed on July 29,2017 )

${ }^{3}$ http://www.theregister.co.uk/2006/02/03

/gm_outsourcing/ (accessed on July 29, 2017)

${ }^{4}$ https://www.gartner.com/doc/2092915/fo

recast-analysis-it-outsourcing-worldwide

(accessed on August 8, 2017)

5 http://www.prnewswire.com/news-

releases/global-it-outsourcing-market-cagrgrowth-of-584-by-2019---trends-

technologies--opportunities-report-2015-

2019---key-vendors-hp-ibm-infosys-

571658261.html (accessed on August 8, 2017)

6http://www.thestar.com.my/business/sme /2013/10/23/outsourcing-industry-set-todouble-in-growth-by-

2017/\#wwHWcEddX7aSIOEd.99 (accessed on August 8, 2017)

\section{References}

1. Ang, S. and Straub, D. W. (1998), 'Production and transaction economies and IS outsourcing: a study of the US banking industry,' MIS Quarterly, 535-552.

2. Bagozzi, RP. and Yi, Y. (1988), 'On the evaluation of structural equation models,' Journal of the Academy of Marketing Science, 16(1), 7494.

3. Barthélemy, J. (2003). 'The hard and soft sides of IT outsourcing management,' European Management Journal, 21(5), 539548.

4. Claver, E., González, R., Gascó, J and Llopis, J. (2002), 'Information systems outsourcing: reasons, reservations and success factors,' Logistics Information Management, 15(4), 294-308. 
5. Cronin Jr, JJ., and Taylor, S. A. (1992), 'Measuring service quality: a reexamination and extension,' Journal of Marketing, 55-68.

6. De Haes, S. and Van Grembergen, W. (2004), 'IT governance and its mechanisms,' Information Systems Control Journal, 1, 27-33.

7. De Haes, S., and Van Grembergen, W. (2005, January), 'IT governance structures, processes and relational mechanisms: achieving IT/business alignment in a major Belgian financial group,' In System Sciences, 2005. HICSS'05. Proceedings of the $38^{\text {th }}$ Annual Hawaii International Conference on Systems Sciences (HICSS).

8. De Haes, S. and Van Grembergen, W. (2008a), 'Analysing the relationship between IT governance and business/IT alignment maturity,' In System Sciences, 2008. HICSS'08. Proceedings of the $41^{\text {st }}$ Hawaii International Conference on Systems Sciences (HICSS).

9. De Haes, S., and van Grembergen, W. (2008b), 'Practices in IT governance and business/IT alignment,' Information Systems Control Journal, 2, 1-6.

10.DeLone, WH., and McLean, E. R. (2003), "The DeLone and McLean model of information systems success: a ten-year update,' Journal of Management Information Systems, 19(4), 9-30.

11.Fornell, CR. and Larcker, D.F. (1981), 'Evaluating structural equation models with unobserved variables and measurement error,' Journal of Marketing Research, 18(1), 39-50.

12.Grover, V., Cheon, MJ. and Teng, J.T.C. (1996), 'The effect of service quality and partnership on the outsourcing of information systems functions,' Journal of Management Information Systems, 12(4), 89116.

13.Gupta, UG. and Gupta, A. (1992), 'Outsourcing the IS function: Is it necessary for your organization?,' Information Systems Management, 9(3), 44-47.

14.Hair, JF, Tatham, RL, Anderson, RE and Black, W. (1998), Multivariate Data Analysis, $5^{\text {th }}$ ed.

Prentice-Hall, NY.

15.IT Governance Institute (2005), 'The Governance Institute Home Page,' accessed on August 8, 2017, available at: www.governanceinstitute.com/

16.Kan, AR. (2003), 'Managing a multibillion dollar IT budget,' Software Maintenance, September 2003, 2.

17.Kern, T. and Willcocks, L. (2000), 'Exploring information technology outsourcing relationships: theory and practice,' Journal of Strategic Information Systems, 9(4), 321-350.

18.Kline, RB. (2005), Principles and Practice of Structural Equation Modelling, Guilford Press,

NY.

19. Korac-Kakabadse, N. and Kakabadse, A. (2001), 'IS/IT governance: need for an integrated model,' Corporate Governance, 1(4), 9-11.

20.Liang, T-P., Chiu, Y-C, Wu, SPJ. and Straub, D. (2011), 'The impact of IT governance on organizational performance,' In AMCIS 2011 proceedings - all submissions, 268, accessed on September 7, 2017, available at: http://aisel.aisnet.org/amcis2011 submissio $\underline{\mathrm{ns} / 268}$

21.Lunardi GL., Becker, JL., Maçada, ACG., Dolci, P. C. (2014), 'The impact of adopting IT governance on financial performance: An empirical analysis among Brazilian firms,' International Journal of Accounting Information Systems, 15(1), 66-81, accessed on August 8, 2017, available at: http://dx.doi.org/10.1016/j.accinf.2013.02.0 $\underline{01}$ 
22.Mangalaraj, G., Singh, A. and Taneja, A. (2014), 'IT Governance Frameworks and COBIT - A Literature Review,' In Twentieth Americas Conference on Information Systems (AMCIS) proceedings, Savannah, 2014 accessed on September 8, 2017, available at: http://aisel.aisnet.org/cgi/viewcontent.cgi?a $\underline{\text { rticle }=1262 \& \text { context }=\operatorname{amcis} 2014}$

23. McFarlan, F. and Nolan, R. L. (1995), 'How to manage an IT outsourcing alliance,' Sloan Management Review, 36, 9-22.

24.Mohamed, N. and Kaur, J. (2012), 'A conceptual framework for information technology governance effectiveness in private organizations,' Information Management \& Computer Security, 20(2), pp. $88-106$

25.Nunnally, J. C. (1978), Psychometric Theory, $2^{\text {nd }}$ ed., McGraw-Hill, NY.

26.Pang, M-S. (2014), 'IT governance and business value in the public sector organizations - The role of elected representatives in IT governance and its impact on IT value in U.S. state governments,' Decision Support Systems, 59, 274-285.

27.Parasuraman, A, Berry, LL. and Zeithaml, V. A. (1991), 'Refinement and reassessment of the SERVQUAL scale,' Journal of Retailing, 67(4), 420-450.

28.Peterson, R. (2004), 'Crafting information technology governance,' Information Systems Management, 21(4), 7-22.

29.Pitt, LF., Watson, RT. and Kavan, C. B. (1995), 'Service quality: a measure of information systems effectiveness,' MIS Quarterly, 19(2), 173-187.

30.Sherman, BA. (1997). Operationalization of information systems technology assessment. Unpublished doctoral dissertation, State University of New York at Buffalo.
31.Symons, C. (2005), 'IT governance framework: structures, processes and communication,' accessed on August 8, 2017, available www.cba.co.nz/download/Forr0511036563 00.pdf

32.Tsai, W-H, Chou, Y-W, Leu, J-D, Chen DC. and Tsaur, T-S. (2015), 'Investigation of the mediating effects of IT governance-value delivery on service quality and ERP performance,' Enterprise Information Systems, 9(2), 139-160, DOI: $10.1080 / 17517575.2013 .804952$.

33.Turel, O. and Bart, C. (2014), 'Board-level IT governance and organizational performance,' European Journal of Information Systems, 23, 223-239.

34.Van Grembergen, W. (2000, May). The balanced scorecard and IT governance, in IRMA Conference, 1123-1124.

35.Weill, P. and Ross, JW. (2004), IT governance: how top performers manage IT decision rights for superior results, Harvard Business School Publishing, Boston, MA.

36.Weill, P. and Woodham, P. (2002), 'Don't just lead, govern: implementing effective IT governance,' accessed on August 8, 2017, available at: http://ssrn.com/abstract_id $1 / 4317319$

37.Zeithaml, V., Parasuraman, A., and Berry, LL. (1990), Delivering Quality Service: Balancing Customers Perceptions and Expectations, The Free Press, NY. 